January 2013

\title{
Preserving Film Preservation in the Digital Era
}

Becca Bastron

San Jose State University, bbastron11@gmail.com

Follow this and additional works at: https://scholarworks.sjsu.edu/ischoolsrj

Part of the Archival Science Commons, and the Film and Media Studies Commons

\section{Recommended Citation}

Bastron, B. (2013). Preserving Film Preservation in the Digital Era. School of Information Student Research Journal, 2(2). https://doi.org/10.31979/2575-2499.020206 Retrieved from https://scholarworks.sjsu.edu/ischoolsrj/vol2/iss2/6

This article is brought to you by the open access Journals at SJSU ScholarWorks. It has been accepted for inclusion in School of Information Student Research Journal by an authorized administrator of SJSU ScholarWorks. For more information, please contact scholarworks@sjsu.edu. 


\title{
Preserving Film Preservation in the Digital Era
}

\begin{abstract}
This paper explores the current controversies surrounding film preservation in the digital era. Questions address the benefits of new technologies and the potential sacrifices to a film's authenticity and designation as a valued historical, social, and cultural artifact. Issues examined include film's frail format, archives's financial and storage limitations, the concept of "the original film," and how current digitization methods affect each of these areas. This paper addresses the recent restorations of two particular films-Fritz Lang's Metropolis (1927) and Alfred Hitchcock's Vertigo (1958)-and concludes that digital technologies are not stable enough to replace traditional preservation methods, but they can greatly increase exposure to lesser-known films and support the general preservation of film.
\end{abstract}

\section{Keywords}

archives, film, preservation, digital

\section{About Author}

Becca Bastron is a library student at San Jose State University, and a passionate film history buff. 


\section{Introduction}

Nearly forty-one minutes into the 1983 restoration of George Cukor's A Star is Born (1954), film historian Ronald Haver was forced to use a montage of production stills and publicity photographs to make up for the still missing footage. Though Haver managed to locate the original soundtrack in its entirety, and most of the film through various motion picture vaults and mislabeled cans, a few portions of footage (cut after the 1954 premiere due to complaints concerning its three-hour running time) remain lost (Warner Bros., n.d.). Perhaps it will take another thirty years to completely restore the film, or perhaps this is the best it is going to get. Film buffs and historians are still waiting, hoping, and praying for the lost forty-five minutes of Orson Welles's The Magnificent Ambersons (1942) to appear on some dusty shelf, in a miscataloged canister, or at an unassuming garage sale somewhere-it has been known to happen. Like A Star is Born, Welles's masterpiece became victim to studio alterations, and the cut footage went missing. ${ }^{1}$ Featuring major stars like Judy Garland (A Star is Born) and Orson Welles, it seems strange that these films have been so neglected and mistreated, and it begs the question: What has become of the "lesser" films, those without the Garlands and the Oscar nominations and the big budgets? Over 50\% of all films made prior to 1951 and roughly 75 to $80 \%$ of all silent films are gone forever (Goldman, 1993; Houston, 1994). But thanks to a somewhat recent shift in perspective that was sparked by the film schools of the 1970s, more and more people regard and acknowledge film as an important and vital part of our cultural heritage, no longer just a shimmering goldmine for the studios and theaters.

It has become a priority to preserve and restore older films before their nitrate-induced expiration date and to properly store and care for contemporary films. Unfortunately, this outlook is not enough to guarantee the locating and restoring of films before decay calls "time's up!" The ultimate goal of preserving a film is to present it in its original format, running time, and crisp black-andwhite or vibrant color - to present it to audiences now the way it was presented to audiences then-so archivists and preservationists run into a mountain of both ethical and technological dilemmas when trying to achieve this often impossible feat. They face issues of authenticity, value, and adaption to modern technology; they are limited by financial restrictions, and a lack of resources and storage space; they are also competing with free and easily accessible digital archives like the Internet Archive and video sharing sites such as YouTube and Google Video. With the rise and prominent nature of the World Wide Web and digitization methods, the archival institution's need to survive often conflicts with the ethics and intentions of the film archivist. Traditional film preservation is not perfect,

\footnotetext{
${ }^{1}$ Filmmaker Peter Bogdanovich told Turner Classic Movies that he believed the footage was literally dumped into the ocean (Grey, 2010).
} 
nor is there an agreed-upon set of standards for archivists to follow, but digital preservation is not the solution. It may prove successful as a marketing tool, it may help film archives achieve greater accessibility, and it may provide assurance that if a film print is destroyed the motion picture itself will survive. However, digital preservation comes with a slew of problems and remains a poor substitute for traditional film preservation.

\section{Issues in Film Preservation}

Make no mistake: The current state of film preservation is not a favorable one. Most moving pictures made before 1950 were shot with cellulose nitrate film, a highly flammable ${ }^{2}$ and chemically unstable film stock that decomposes at an alarming rate when neglected, and at a somewhat slower rate when ideal storage conditions are employed (Read \& Meyer, 2000). Add to this the fact that early cinema was considered a commercial asset with little to no cultural value, and one senses the film archivist's frustrations and struggles to preserve what is now considered "an expression of the cultural identities of peoples [that] form[s] an integral part of a nation's cultural heritage....and, as such, constitute[s] important and often unique testimonies, of a new dimension, to the history, way of life and culture of peoples" (United Nations Educational, Scientific and Cultural Organization, 1980). During Hollywood's heyday, once a film was removed from theater circulation and had exhausted its monetary gains there was no reason to keep it around or protect it for further use.

These moving images, apparently thought of as durable...even while experienced in the course of being progressively dissolved, were repeatedly shown in different locations and at different times until they were completely destroyed at last_-that is, when the physical condition of the carrier was in a state so disastrous as to make its further exhibition virtually impossible .. . Exploited to the utmost, their carriers had no further reason to exist; their destruction was not only inevitable but desirable insofar as new carriers and new images had to be created for commercial reasons. (Usai, 2001, p. 67)

Because of such treatment, preservationists and restorers are often left with the task of filling in the blanks to the best of their abilities.

After 1950, a shift towards cellulose diacetate film (a safer, less flammable alternative to nitrate) gave enthusiasts a somewhat false sense of security until it was discovered that acetate negatives, though more long-lasting

\footnotetext{
${ }^{2}$ Not only does nitrate film burn twenty times faster than wood, but it also holds enough oxygen to keep burning underwater (Slide, 1992).
} 
than nitrate film, deteriorate at a much faster speed than initially expected (Read \& Meyer, 2000). Responsible for the term "vinegar syndrome," which was not identified until the early 1980s, acetate film gives off a strong odor of vinegar when decomposing and can easily contaminate nearby prints (Goldman, 1993). This realization was made around the same time filmmaker and preservation advocate Martin Scorsese noticed that the original print of his film Taxi Driver (1976), made only five years earlier, was already a victim of color degradation: "At the time, the term 'vinegar syndrome'...had not even been invented by film archivists. All we knew was that prints were starting to shrink, become curled, and would be unprojectable by the time their...unpleasant acidic smell had reached almost unbearable levels" (Scorsese, 2001). Under such circumstances, it would seem that digital technology is a godsend: Transfer everything onto convenient digital files and throw away those dangerous nitrates and stinky acetates.

Assigning value to films - which one has it and which does not-poses another challenge for archivists. They agree that film itself is of significant value, but in a field lacking both financial resources and facility space many are forced to surrender films to a hierarchical order to determine who the survivors will be. While it may not seem difficult to recognize important films in contemporary culture, it is impossible to determine which films will be considered important to future generations. Filmmaker David Forbes (2009) points out, "what may not look important today may be vital in 20 years' time" (p. 42). If classic Hollywood held this belief, today's archivists would have a much easier job. In an effort to avoid old Hollywood's mistake - to "make up for the sins of the past" (Houston, 1994, p. 15)-many archival institutions adopted the idealist notion that everything should be preserved and are now overwhelmed with material they neither have the housing nor the funding to care for.

The notion that all films should be saved has been quietly superseded by factual evidence, but it is still ingrained in the archives' mentality, so much so that it is still taken for granted, like the aspiration presiding over the current attempts to preserve (and make accessible) the Internet in its entirety. (Usai, 2009, p. 15)

It is impossible to preserve everything, but archivists are careful with such compromises. If focus is given exclusively to films deemed crucial by contemporary standards and values, those gems in the rough not yet appreciated by existing perspectives may slip through the cracks. Much the same way that the librarian presents a varied and unbiased collection to the public, the film archivist must consider all films as equals. Film author and critic Penelope Houston wrote, "Once a film has been destroyed, it is gone for good; as long as it lives, someone, 
some day may find a reason to look at it" (1994, p. 82). Still, the question of resources is a difficult obstacle to overcome, and prioritization and commercial interests hold an inevitable place in the debate.

\section{The Commercial Influence on Preservation}

Every year since 1989, the Library of Congress's National Film Preservation Board (NFPB) has selected up to 25 "culturally, historically or aesthetically significant films" to add to the National Film Registry and essentially push for preservation (NFPB, n.d.). Eligible films must be "at least 10 years old, though they need not be feature-length or have had a theatrical release in order to be considered. The [NFPB's] intent is that the broadest possible range of films be eligible for consideration" (NFPB, n.d.). However, perusing a list of selections between 1989 and 2011, one cannot help noticing the majority of popular Hollywood films (Internet Movie Database, n.d.). In fact, with selections like Casablanca (1942), Citizen Kane (1941), The Grapes of Wrath (1940), and Gone with the Wind (1939), the year 1989 was a veritable who's who of the American Film Institute's (AFI) popular "100 Years...100 Movies" lists (AFI, n.d.). While the NFPB lists have every good intention of designating items for "immediate preservation," the "AFI lists are broadcast each year and clearly also function in support of the marketing of such titles to home video" (Ricci, 2008, pp. 444-445). Ricci, Assistant Professor in UCLA's Film, Television, and Digital Media Department, points out that these lists "have been criticized for establishing canons that effectively exclude works by women and minority communities," as well as for their "narrow construction of film history and for a lack of scholarly and/or cinephilic justification" (2008, p. 444).

The popularity of such "100 Best" lists is incredibly destructive to film preservation; public attention is drawn to the masterpieces that will sell, and company grants and sponsorships often require their funds to go toward the restoration of a project that may or may not be in urgent need of care (Kilcoyne, 2010). "This can be incredibly frustrating and painful for archivists who see the same core titles in demand" and the same neglected titles left by the wayside (Kilcoyne, 2010, p. 59). Commercial value has a big impact on the success and/or survival of archival institutions and film preservation in general. ${ }^{3}$ Stuck in a catch-22, the easiest way for archives to gain financial support is to preserve the determined classics for future re-releases while lesser-known films that desperately need attention cannot bring in the required funding to attract that attention.

\footnotetext{
${ }^{3}$ The prevailing commercial value of film is evident in Ted Turner's remark following his purchase of MGM's film library: "We've got Spencer Tracy and Jimmy Cagney working for us from the grave" (Gracy, 2007a, p. 47).
} 


\section{Access vs. Preservation}

The effect of commercial interests on preservation is clear, but sometimes preservation itself is the problem. While most archivists acknowledge the importance of accessibility and exposure, there is no universal code on how access to preserved films should be handled. Film is a delicate format, and sometimes its safekeeping challenges accessibility. In an attempt to protect their collection and (whether intentionally or not) discourage access, some archives, such as Britain's National Film and Television Archive, require a small fee from students, researchers, and historians (Houston, 1994). If a viewing print does not exist, the researcher, who is expected to pay the cost of having one made, has two options: a flat-out refusal, or a wait of several months (Houston, 1994). Many archivists are frustrated by such occurrences, including Prelinger (2009):

I continue to be struck by the divergence between our theoretical acceptance of access as a goal and the poor state of access that actually reigns. While expanding access has become a relatively uncontroversial objective, its implementation is roadblocked by constraint, uncertainty, and ambivalence. (p. 164)

Part of this ambivalence stems from the unavoidable fact that the fragility of an original film brings it closer and closer to extinction every time it is viewed, transferred, or handled in any way. The International Federation of Film Archives (FIAF) states in its Code of Ethics that archives "will deny access rather than expose unique or master material to the risks of projection or viewing if the material is thereby endangered" (2002, section 1.2). In spite of this, it is impossible to avoid the summation that "use justifies archives" and "access adds context and value" (Prelinger, 2009, p. 170). How can a film possibly hold onto its value if it is never seen? This is where digital preservation can help.

\section{Digital Technologies: Benefits and Disadvantages}

The importance of access to film archives is universally agreed upon but encouraged with a tinge of hesitation. Institutions understand that neither they nor the films themselves can handle a high demand for access, but access and exposure encourage public awareness, promote lesser-known films, and, in turn, instigate financial support. Digitization may be a wonderful solution to this conflict of interests, and it has already shown promising results in the UK's Moving History project (http://www.movinghistory.ac.uk), the British Film Institute's Screen Online project (http://www.screenonline.org.uk/education/index.html), and the San Francisco- 
based Internet Archive (http://www.archive.org/details/moviesandfilms). All offer free access to digitally streaming film and video archives. Though Screen Online is limited to academic circles, the digitization and otherwise free and easy access to films by all three organizations means exposure to works that have previously been ignored. Undoubtedly for archivists, "this implies the active promotion of [their] collections, especially of material that has hitherto remained more or less invisible" (Gray \& Sheppard, 2004, p. 116).

The instability of nitrate film, which can self-ignite at 300 degrees and has also done so at only 106 degrees, ${ }^{4}$ has resulted in several cases of facility fires and permanent gaps in motion picture history (Slide, 1992). There are too many such instances to mention, but one of the more devastating was the 1980 fire at the Cinémathèque outside of Paris - at the time, considered one of the most prestigious and heralded of all film archives (Slide, 1992). It is estimated that around 15,000 reels of film were lost, including many original prints (Slide, 1992). These originals are now lost forever, but digital technology can keep future losses to a much less threatening level. There is still no way to permanently preserve film, but until such a system is discovered, digital methods offer a promising defense against complete annihilation. They certainly enable archivists to breathe a bit easier.

While acknowledging the benefits of digital preservation-namely, unlimited storage space and easier access-film scholar Karen Gracy points out that "the issues of format obsolescence, authenticity, integrity, scalability, and economic incentives for providing preservation services weigh down the [archival] community in complex challenges" (2007b, p. 186). Dietrich Schüller of the Austrian Academy of Science also comments on the problem of "format obsolescence": "Thanks to the technical development over the past 20 years, we have experienced ever shorter commercial life cycles of dedicated audio and video formats" (2008, p. 5). Utilizing a technology that seems to morph faster than we can keep up with suggests that digital files and records will require reformatting at least every three to five years (Mattock, 2010). This is a considerably shorter lifespan than film.

In a Hollywood Reporter review of the Academy of Motion Picture Arts and Sciences (AMPAS) archival report, "The Digital Dilemma: Strategic Issues in Archiving and Accessing Digital Motion Picture Materials," Giardina (2007) affirms that AMPAS has already "identified instances where digital content could not be accessed after only 18 months" (para. 4). She goes on to paraphrase AMPAS project leader Milt Shefter on the subject:

\footnotetext{
${ }^{4}$ This occurred during the summer of 1949 in New York City (Slide, 1992).
} 
Shefter noted that a requirement for any preservation system is that it must meet or exceed the performance characteristic benefits of the current analog photochemical film system. According to the report, these benefits include a worldwide standard; guaranteed long-term access (100-year minimum) with no loss of quality; the ability to create duplicate masters to fulfill future (and unknown) distribution needs and opportunities; and immunity from escalating financial investment. "There's nothing in the digital world that comes close to this at this point," [Shefter] said. (as cited in Giardina, 2007, para. 6-7)

Because digitized copies themselves require repeated reformatting to keep up with each technological advancement, and because this is a costly process, they do not alleviate much financial pressure. AMPAS's report "suggests that the annual cost of preserving film archival master material is $\$ 1,059$ per title, and the cost of preserving a $4 \mathrm{~K}^{5}$-digital master is $\$ 12,514 "$ (Giardina, 2007, para. 8). Digital technologies also run the risk of hard drive crashes, viruses, unauthorized alterations, and physical damage. DVDs and Blu-ray discs are often considered improvements in format, but film historian Eddie Muller reminds us that "a film gets scratched and it still plays. Scratch a DVD, it's kaput” (2011, para. 21).

From the audience perspective, digitization greatly alters the experience of viewing a film. Many theaters are in the process of or have already converted to digital exhibition methods. There are nostalgic reasons for protesting these methods, but there are also legitimate consequences to digital and/or satellite exhibition.

[The] ethical principles of archival preservation...do not tolerate the diminished image quality that is currently inherent in even the best digital technologies. Even if this dilemma is ultimately solved in technological terms, with digital formats approaching an acceptable degree of emulation, we dispense with the materiality of the film experience as a historical phenomenon. Such a loss is hard to qualify. (Kilcoyne, 2010, p. 63-64)

No doubt audiences will also have issues with theaters who charge the same price of admission for a lesser-quality DVD.

Obsolescence is another consequence of digital exhibition. High Definition (HD), the format that many theaters are now using when they convert to digital, is "not yet an entirely stable format, but the technology has already moved on" (Crofts, 2008, p. 7). "Our expertise is in danger of becoming out of date even before it is fully mastered" (Crofts, 2008, p. 7). Clive Ogden at Kodak

\footnotetext{
5 " $\mathrm{K}$ " refers to the means of measuring digital projection resolution in pixels: A full screen $2 \mathrm{~K}$
} image is essentially $2048 \times 1536$ pixels, while $4 \mathrm{~K}$ is $4096 \times 3072$ pixels (CELCO, n.d.). 
contends that, while digital projection offers a $2 \mathrm{~K}-4 \mathrm{~K}$ resolution, the current Hollywood standard, ${ }^{6}$ film stock is at least a $6 \mathrm{~K}$ (as cited in Crofts, 2008). It is clear that digital methods are not a substitute for film, but there are reasons to utilize their benefits.

\section{Case Studies in Preservation: Metropolis and Vertigo}

In 2010, a fully restored version of Fritz Lang's Metropolis (1927) hit U.S. movie theaters and reinstated much of the film's plot and character development. For the first time since its 1927 Berlin premiere, the film was shown in its entirety. The missing footage, roughly twenty-five minutes in length, was presumed destroyed before Argentine archivist Fernando Peña tracked it down in a Buenos Aires archive.

Metropolis is an interesting case because there have been so many versions available, none of them complete until now. Archivists are primarily concerned with preserving the original film, but when there are multiple versions floating around, it is difficult to determine which one holds more value over another. Mattock (2010) explores this confusion by posing the question: If we agree that the original Metropolis pertains solely to the 1927 release that screened in Berlin, what do we call the U.S. version with English intertitles shown in 1920s America? Is this the original film as well? What about the second German version taking its cue from a rearranged American version, or Germany's sound film from the 1960s? Then there is Giorgio Moroder's 1984 interpretation adding color and a rock soundtrack. Are all of these considered Lang's Metropolis, and does one deserve more attention, in terms of preservation, over another? Moroder himself claimed that he "didn't touch the original, because there is no original" (as cited in Mattock, 2010, pp. 80-81), and film archivist Martin Koerber, also the restoration director for the 2010 release, agrees:

Many have, at some point, seen something on the screen called Metropolis. But what did they see? Certainly not the film written in 1924 by Thea von Harbou and directed by Fritz Lang in 1925/26, because that film ceased to exist in April 1927. (as cited in Ricci, 2008, p. 439)

In a case such as this, digital preservation can alleviate some of the pressure and confusion. From what we know of digitization's drawbacks, the best way to guarantee a film's survival is to preserve the actual print. Indisputably, the 2010 restoration of Metropolis (the closest to Lang's 1927 version) should be preserved, but this does not necessarily render all other versions obsolete or

${ }^{6}$ It was only around 2006 when the standard was $1.3 \mathrm{~K}$; any exhibitors who purchased these projectors are already sitting on dead technology (Crofts, 2008). 
insignificant. They are an important part of the restoration's history and process toward completion, they show how a missing reaction shot can completely alter a film's tone, and they offer proof that incomplete or imperfect prints can still find an appreciative audience. Digitization can keep these versions alive through alternatives like DVD bonus features-which are becoming more popular and more expected - and online film archives. (The new restoration itself is available on YouTube.)

Digital technologies are also responsible for the restoration itself. Early in the 1970s, the 35-millimeter print was "reduced to a 16-millimeter negative" before removing any dust or hair particles or attending to any scratches or smudges (Rohter, 2010, para. 11). These defects were transferred over. With so much damage to work through, "restoring the Argentine reels required the latest in digital technology" (Rohter, 2010, para. 11). In previous versions of the film, there is a tall, slender character simply referred to in the credits as "The Thin Man." He has very little to do with the film's plot and acts as nothing more than a "glorified butler" (Rohter, 2010, para. 13). The digitally restored scenes, however, show that "The Thin Man" is in fact "a much more sinister figure" and is vital to the plot's development (Rohter, 2010, para. 13). The new restoration also expands the film's political and social themes. Calling the film typical science fiction is now a vast oversimplification that no longer applies (Rohter, 2010). If not for digital technologies, Lang's vision would remain incomplete and misunderstood.

The 1996 restoration of Alfred Hitchcock's Vertigo (1958) is not really a restoration at all, but a reconstruction. Restoration refers to the attempt and manipulation process to duplicate the original, while reconstruction is a rearranging or new interpretation of the original (Read \& Meyer, 2000). Vertigo was originally shot using VistaVision cameras, a "widescreen format [that quickly became extinct and] featured horizontally based images on regular $35 \mathrm{~mm}$ film...[offering] superior resolution by effectively doubling the size of the image" (Kilcoyne, 2010, p. 66). Such obsolete formats present their own difficulties to restorers, but the terrible state of Vertigo's sound track and original score was even more challenging. Opting to digitize the dialogue track, which rendered the original Foley track, or sound effects track, unusable, restorers Robert A. Harris and James C. Katz then had to create, record, and mix new effects ${ }^{7}$ - some of which were included for the sole purpose of covering up original "hisses, pops, and bangs" (Kilcoyne, 2010, pp. 66-67). While Harris and Katz consider these

\footnotetext{
${ }^{7}$ According to Dave Kehr of The New York Times, "digital restoration is often a zero-sum game, in which the erasing of one flaw produces another [and] we continue to move further from the look and feel of the first-generation film" (2009, para. 7).
} 
alterations improvements, ${ }^{8}$ there is an underlying discomfort that cannot be ignored.

With the passage of time and the introduction of new technologies, flaws once considered minor are no longer forgiven. The pops and glitches, the occasional dust particles, were not considered imperfections to early moviegoers - they were simply part of the film experience. Alterations like those by Harris and Katz are made to fit newer standards and expectations, and ultimately compromise a film's authenticity and historic value. The film becomes a contemporary work, not an accurate depiction of the past. Kehr (2009) makes a case against the popularity of HD imagery, stating,

For Blu-ray to look its best it requires picture and sound images of the finest, most pristine quality. That's not difficult to come by in a contemporary release like "Transformers: Revenge of the Fallen" (the best-selling Blu-ray of 2009), but is somewhat more problematic for a film made in Germany in 1926. Blu-ray exaggerates the faults in older material..." (para. 6).

He proposes that such standards are creating a generation of viewers who will reject older films that fail to transfer as well as the latest blockbuster.

Another contention for archivists is retaining what Mattock (2010) and Ricci (2008) call a film's "aura." The aura of Metropolis includes, as a silent film, a live orchestra presenting the score, Berlin in the late 1920s, and perhaps a scratch here or a tiny tear there-a sense of its origins and fragile format. Vertigo's aura comprises those lamentable pops and hisses, those brief but ambitious exhibition methods of the 1950s, and those eye-popping Technicolor saturations. Archivists do not sacrifice such auras lightly, but it is impossible to maintain a film's aura in full if it includes another time and place, or an extinct format. We cannot travel back in time to Berlin in the 1920s or America in the 1950 s - the world is not a Woody Allen movie. There are varying degrees of compromise, but restorers cross a line when "enhancing images and sound tracks... begin to corrupt the original work" - an argument that can be made for Vertigo's reconstruction and the newer HD expectations (Ricci, 2008, p. 442). Unfortunately, archivists and audiences have little control over this. Voicing how many film enthusiasts feel, Kilcoyne (2010) admits, "if I only get to watch and rewatch a version of Vertigo because Universal spent over a million dollars...allowing Harris and Katz to restore it with a superfluous seagull, then so be it” (p. 70). Commercially successful restorations like these increase a film's

\footnotetext{
${ }^{8}$ They even "claim that Hitchcock would have used digital stereo technologies on the sound track had they been available in 1958" (Ricci, 2008, p. 442).
} 
chance of survival, but the long-term effect on archival institutions and less popular films results in a bittersweet victory.

\section{Conclusion}

The concerns raised by Vertigo's reconstruction may never be fully resolved. Some contend that Hitchcock would have been proud (Ricci, 2008), while others, like FIAF (2002), consider such manipulations unethical. Using digital technologies in this way will always raise some eyebrows and spark debate, but the recent success of Metropolis has given us a rendition even closer to the original, and this cannot be ignored.

The case of Metropolis is one example of an ideal approach to using digital methods. A less than ideal approach would favor digital preservation over film preservation in all cases. When digital preservation was first introduced, it was promising, as most new technologies are. But as tends to happen with many new technologies, imperfections have been revealed over time which contrast with previous assumptions: Digital preservation costs more, not less, than film preservation; digital formats change rapidly and have a much shorter lifespan than film; they are susceptible to manipulation, viruses, and scratches that render them unplayable; and their quality is not up to par with film. These limitations cannot be ignored and are reason enough to endorse traditional film preservation methods. Digital methods do, however, increase public awareness of an archive's collection, improve accessibility of lesser-known films, encourage financial and cultural support, and generally maintain the consensus that film holds an important place in our history and culture. These benefits cannot be ignored either.

Film preservationist Paolo Cherchi Usai likens the archivist to a "physician who has accepted the inevitability of death even while he continues to fight for the patient's life" (as cited in Ricci, 2008, p. 438). Although digital methods can help with this life or death struggle, they have a long way to go before replacing traditional film preservation entirely.

\section{References}

American Film Institute. (n.d.). AFI's 100 years...100 movies. Retrieved from http://www.afi.com/100years/movies.aspx

CELCO. (n.d.). $4 K / 2 K$ resolution table. Retrieved from http://www.celco.com/FormatResolutionTable4K.asp

Crofts, C. (2008). Digital decay. The Moving Image, 8(2), xiii-35.

Forbes, D. (2009). Film archives: A decaying visual history. African Research \& Documentation, 110, 37-43. 
Giardina, C. (2007, November 5). AMPAS: Do your archiving before it's too late. Hollywood Reporter.

Goldman, N. (1993). Organization and management of film archives and libraries. Collection Management, 18(1/2), 41-48.

Gracy, K. F. (2007a). Film preservation: Competing definitions of value, use, and practice. Chicago, IL: Society of American Archivists.

Gracy, K. F. (2007b). Moving image preservation and cultural capital. Library Trends, 56(1), 183-197.

Gray, F., \& Sheppard, E. (2004). Moving history: Promoting moving image archive collections in an emerging digital age. The Moving Image, 4(2), 110-118. doi: 10.1353/mov.2004.0026

Grey, B. M. (2010, April 24). Magnificent Ambersons lost footage likely at bottom of ocean. Retrieved from http://www.suite101.com/content/magnificent-ambersons-lost-footagelikely-at-bottom-of-ocean-a229513

Houston, P. (1994). Keepers of the frame: The film archives. London: British Film Institute.

International Federation of Film Archives. (2002). Code of ethics. Retrieved from http://www.fiafnet.org/ fiafnet/uk/members/ethics.html

Internet Movie Database. (n.d.). National film preservation board, USA. Retrieved from http://www.imdb.com/event/ev0000468/1989

Kehr, D. (2009, December 30). The ballad of Blu-ray and scratchy old film. The New York Times. Retrieved from http://www.nytimes.com/2010/01/03/movies/homevideo/03kehr.html?pag ewanted $=1$

Kilcoyne, S. P. (2010). You shouldn't have been that sentimental: Film restoration ethics in Hitchcock's Vertigo. Journal of Information Ethics, 19(1), 57-73. doi: 10.3172/JIE.19.1.57

Mattock, L. K. (2010). From film restoration to digital emulation: The archival code of ethics in the age of digital reproduction. Journal of Information Ethics, 19(1), 74-85.

Muller, E. (2011, February 13). Interview by Self-Styled Siren. "It can give a film new life": A talk with Eddie Muller of the Film Noir Foundation [Web log post]. Retrieved from http://selfstyledsiren.blogspot.com/2011/02/it-cangive-film-new-life-talk-with.html

National Film Preservation Board. (n.d.). About the board. Retrieved from http://www.loc.gov/film/filmabou.html

Prelinger, R. (2009). Points of origin: Discovering ourselves through access. The Moving Image, 9(2), 164-175. doi: 10.1353/mov.2010.0005

Read, P., \& Meyer, M. (2000). Restoration of motion picture film. Oxford: Butterworth-Heinemann. 
Ricci, S. (2008). Saving, rebuilding, or making: Archival (re)constructions in moving image archives. The American Archivist, 71(2), 433-455.

Rohter, L. (2010, May 4). Footage restored to Fritz Lang's 'Metropolis.' The New York Times. Retrieved from http://www.nytimes.com/2010/05/05/movies/05metropolis.html

Schüller, D. (2008). Socio-technical and socio-cultural challenges of audio and video preservation. International Preservation News, 46, 5-8.

Scorsese, M. (2001). Preface. In P. C. Usai, The death of cinema: History, cultural memory and the digital dark age. London: British Film Institute.

Slide, A. (1992). Nitrate won't wait: Film preservation in the United States. Jefferson, NC: McFarland \& Company, Inc.

United Nations Educational, Scientific and Cultural Organization. (1980, October 27). Recommendation for the safeguarding and preservation of moving images. Retrieved from http://portal.unesco.org/en/ev.phpURL_ID=13139\&URL_DO=DO_TOPIC\&URL_SECTION=201.html

Usai, P. C. (2001). The death of cinema: History, cultural memory and the digital dark age. London: British Film Institute.

Usai, P. C. (2009). Are all (analog) films “orphans"?: A predigital appraisal. The Moving Image, 9(1), 1-18. doi: 10.1353/mov.0.0028

Warner Bros. (n.d.). A Star is Born. Retrieved from http://www.wbshop.com/Star-Is-Born-A1954/1000000486, default,pd.html?cgid=DVD 